\title{
PELATIHAN SENI KALIGRAFI ISLAM DI PESANTREN THAWALIB GUNUANG
}

\author{
Hanafi \\ Olvyanda Ariesta \\ Ikhsan Maulana \\ Program Studi Pendidikan Seni Kriya/ Fakultas Seni Rupa Dan Desain Institut Seni \\ Indonesia Padangpanjang \\ Jl. Bahder Johan Padangpanjang Sumatera Barat/27128 \\ doanghanafi80@gmail.com _Olvyanda7@gmail.com ikhsan alkhot@gmail.com
}

\begin{abstract}
ABSTRAK
Pelatihan kaligrafi bagi siswa terutama di pesantern sangat di perlukan. Hal ini untuk mendukung proses pembelajaran agar lebih terkoordinir dengan baik. Namun tidak semua pesantren yang memberikan perhatian lebih terhadap materi kaligrafi. Padahal mata pelajaran kaligrafi memberikan dampak cukup besar bagi seseorang yang mempelajarinya. Seseorang yang belajar kaligrafi akan memiliki kepekaan rasa dan kehalusan perasaan. Kegiatan pelatihan kaligrafi ini lah yang dilaksanakan di pesantren modern Thawalib Gunung. Siswa tingkatan Aliyah selama ini belum dibekali pengetahuan mendalam mengenai membuat kaligrafi dengan beragam alat seperti kalam dan juga kuas. Membuat kaligrafi tentunya mmebutuhkan pengetahuan dan pengalaman tersendiri sehingga hasilnya menarik. Kegiatan ini dimulai dengan memberikan materi tentang jenis khat kaligrafi dan bagaimana karakter dari masing masing khat tersebut. Selanjutnya siswa diperkenalkan dengan teknik dasar kaligrafi menggunakan kalam. Untuk mempelajari kaligrafi, maka siswa harus mencoba dahulu bagaimana menggunakan kalam dan menorehkannya di kertas.Latihan ini dimulai dengan membuat masing-masing khat. Selanjutnya siswa akan belajar mengenai membuat tulisan kaligrafi dengan menggunakan kuas. Penggunaan kuas juga bertujuan agar siswa mampu lebih mengeksplorasi lagui berbagai bentuk khat yang ada. Di materi akhir siswa diberi kebebasan membuat khat dengan cat dengan beragam warna untuk menghasilkan beragam bentuk khat yang menarik.
\end{abstract}

Kata Kunci : Pelatihan, Kaligrafi, Karakter 


\section{PENDAHULUAN}

Pendidikan formal yang selama ini dilaksanakan disekolah dan institusi pendidikan bertujuan untukk memberikan pengetahuan dan pemahaman kepada peserta didik mengenai apa yang diajarkan. Tujuan dari pembelajaran pada dasarnya untuk meningkatkan kemampuan siswa setelah memperoleh pengalaman. (Anin Ditto, Yulimarni, 2020, p. 39). Selain pendidikan formal untuk mendapatkan ilmu pengetahuan, para siswa perlu juga mendapatkan tambahan wawasan pengetahuan sesuai dengan bidang ilmunya atau penunjang dari keilmuan yang dipelajari selama ini. Pendidikan seni disekolah diberikan karena keunikan, kebermaknaan dan kebermanfaatannya terhadap kebutuhan perkembangan peserta didik melalui pendekatan estetik. (Sundari et al., 2018, p. 93). Program yang biasanya dimasukkan kedalam bagian ekstrakurikuler ini sangat berguna untuk pembentukan karakter siswa. Salah satu contoh kegiatan pelatihan tambahan di sekolah adalah pelatihan seni kaligrafi islam. Kegiatan ini sangat bermanfaat bagi siswa terutama yang belajar di pesantern atau madrasah. Kegiatan pelatihan pada dasarnya memiliki makna ganda yang juga berperan dalam pembentukan karakter seseorang. Apalagi kegiatan pelatihan yang berhubungan dengan seni rupa atau seni visual yang untuk menghasilkan suatu karya yang baik diperlukan kombinasi antara ketelitian, kecermatan, kesabaran disamping keahlian yang dimiliki oleh sipembuatnya.

Kegiatan pelatihan kaligrafi ini dilaksanakan di pesantren Thawalib Gunung. Tujuan dilaksanakannya pelatihan, sesuai dengan tuntutan Pendidikan di Indonesia sebagai bagian dari pembentukan budi pekerti, pembentukan sikap dan mental yang terpuji yang berakar dari nilai-nilai budaya bangsa. (Yanuarmi et al., 2019, p. 71) .Pesantren Thawalib Gunung adalah pesantren modern berbasis pendidikan islam. Siswa selama ini diberikan pendidikan karakter seperti pramuka dan olah raga. Kegiatan ini secara nyata sangat memberikan kontribusi positif untuk pembentukan karakter siswa. Namun untuk kegiatan pelatihan seni kaligrafi islam, siswa masih belum mendapatkan metode pelatihan yang baik, dikarenakan tidak adanya guru dengan latarbelakang pendidikan senirupa yang menguasai seni kaligrafi islam. Padahal siswa di Pesantren Thawalib Gunung disamping memiliki karakter kuat dan ilmu agama yang juga memadai juga perlu diperkenalkan dengan seni melukis kaligrafi islam. Bidang ilmu 
seperti ini sebenarnya sangat relevan dengan apa yang dipelajari oleh siswa selama ini dikarenakan kaligrafi islam merupakan salah satu bidang seni dalam islam yang sudah mendunia. Apalagi dengan metode pendidikan asrama, tentunya siswa memiliki waktu lebih banyak untuk belajar berbagai hal positif mengenai pembentukan karakter.

Menulis kaligrafi islam merupakan salah satu seni dalam mendalami dan mempopulerkan tulisan arab yang sudah dikenal secara global. Menurut Susanto (2012: 210), kaligrafi berasal dari kata kalios yang berarti indah dan graph yang berarti tulisan. Sehingga dapat dikatakan bahwa kaligrafi adalah tulisan atau aksara yang indah. Menurut Ali, kaligrafi merupakan seni dalam islam yang merupakan suatu seni artistik tulisan tangan. (Gunawan, 2016, p. 45)

Dalam perkembangannya kaligrafi telah bertransformasi dimana saat ini bukan hanya sekedar belajar mengenai tulisan indah yang berkaidah, namun juga mulai dikembangkan ke konsep visual art atau kesenirupaan itu sendiri dengan mempertimbangkan berbagai unsur senirupa yang ada. Menurut Susanto (2012: 210) menjelaskan bahwa perkembangan kaligrafi arab tak lepas dari pengaruh ornamen yang ada dimana kaligrafi bisa terikat oleh aturan baku tentang penulisan kaligrafi itu sendir, namun bisa juga menjadi ekspresi dari seniman yang membuatnya. Selanjutnya Sirajuddin menyatakan bahwa ungkapan kaligrafi berarti tulisan indah. (1988: 1)

Kegiatan ini memberikan pemahaman mengenai seni menulis khat kaligrafi tersebut sampai pelaksanaan praktek sesuai dengan metode yang tepat sehingga akan memberikan manfaat signifikan bagi siswanya. Dengan kegiatan ini akan membentuk kedisiplinan, kesabaran dan ketekunana dalam menulis kaligrafi tersebut. Tentunya pelatihan ini akan memberikan dampak yang signifikan untuk pembentukan karakter peserta nantinya.

Melihat dari analisis situasi diatas, maka dapat dirumuskan beberapa permasalahan mitra antara lain :

1. Sebagai sebuah Yayasan pesantern islam modern, belum ada prestasi siswa terkait kaligrafi islam. Prestasi tentunya menjadi salah satu tolak ukur dalam melihat hasil pembelajaran. Dan suatu prestasi tentunya lahir dari proses pembelajaran yang dilaksanakan secara tersistematis.

2. Kurangnya guru yang memiliki latar belakang seni rupa dan memahami mengenai kaligrafi islam. Guru seni 
yang ada dengan latar belakang seni pertunjukan dan tentunya kurang menguasai bidang seni rupa terutama seni lukis Kaligrafi

3. Diperlukan variasi kegiatan ekstrakurikuler yang berhubungan dengan agama islam yang juga bisa membantu menguatkan karakter siswa. Dengan ekstrakurikuler seperti pramuka dan marching band, siswa perlu diberi materi yang lain yang berhubungan dengan ketekunan dan kesabaran.

4. Banyaknya bakat senirupa dari siswa namun belum bisa dioptimalkan. Bakat tersebut ditunjukkan siswa dengan menggamabar dan membuat lukisan dari cat air.

\section{Sebagai sebuah pesantren modern dengan sistem pendidikan terpadu, Pesantren Thawalib Gunung} memiliki target untuk memaksimalkan setiap potensi yang ada di siswanya. Potensi tersebut tentunya harus digali dan dikembangkan. Berbagai kegiatan pengembangan bakat siswa dilaksanakan untuk memenuhi target tersebut. Apalagi siswa yang ada jumlahnya sangat banyak dan dengan beragam bakat dan minat yang dimilikinya. Prestasi siswa seperti dalam bidang olah raga, sains dan kepramukaan, tarik suara, menari dan lainnya selalu diasah secara berkala. Apalagi untuk bidang kepramukaan dan olah raga mereka dilatih oleh tenaga profesional yang berkompeten di bidangnya. Namun untuk bidang keahlian seni rupa terutama yang berhubungan dengan seni lukis kaligrafi, belum ada guru yang berkompeten dibidangnya sehingga kegiatan seperti ini hanya menjadi sampingan dan tidak terlalu difokuskan. Padahal dilihat dari tugas siswa dalam bidang seni rupa seperti menggambar dan melukis, ternyata banyak sekali yang berbakat, namun belum bisa dioptimalkan. Gurupun menyampaikan bahwa ada beberapa anak yang tertarik belajar seni lukis kaligrafi dan berbakat, namun guru tidak bisa mengarahkannya karena keterbatasan kemampuan yang dimilikinya. Permasalahan ini yang dihadapi oleh sekolah sehingga mereka sangat membutuhkan pelatihan mengenai keilmuan dibidang seni kaligrafi. Pengenalan aturan baku dalam penulisan huruf kaligrafi islam (khat) dan juga bagaimana untuk mengembangkannya menjadi seni kaligrafi dengan berbagai dekorasi yang menarik perlu diketahui oleh siswa dan guru sehingga bisa diterapkan di sekolah.

Dalam suatu pelatihan tentunya diharapkan dapat dilaksanakan dengan efektif. Efektif atau tidaknya suatu pelatihan sangat tergantung pada lengkap 
atau tidaknya perencanaan dan lancar tidaknya proses pelaksanaan. (Zein, 2010:60). Dengan adanya kegiatan pelatihan kaligrafi untuk siswa dan guru di Pesantren Thawalib Gunung, diharapkan bisa menjadi motivasi tersendiri bagi siswa yang tertarik mendalami masalah seni lukis kaligrafi. Apalagi dengan potensi yang dimiliki oleh siswa, kegiatan in tentunya akan sangat bermanfaat bagi pengembangan bakat dan kemampuan yang mereka miliki. Selain itu pelatihan kaligrafi merupakan pelatihan kecakapan (life skill) yang sangat berguna bagi santrinya terutama nanti setelah tamat dari pesantren. (Ihsan, n.d., p. 3)

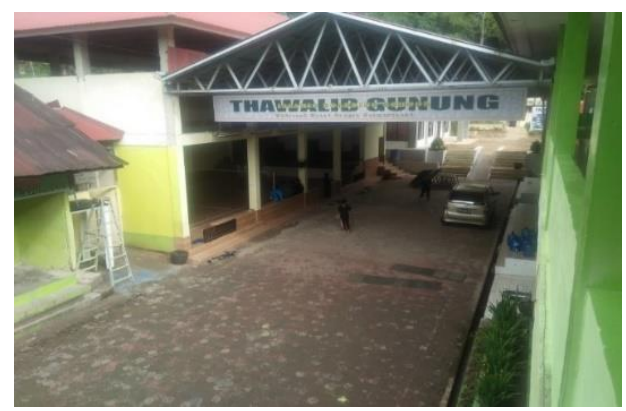

\section{Gambar 1}

Potret Pondok Pesantren Modern Nurul Ikhlas

(Foto Olvyanda, 2019)

\section{PEMBAHASAN}

\section{A. Metode Pelaksanaan}

Hubungan antara pelatihan

kaligrafi arab dengan kreativitas siswa dapat dilihat dari kegiatan yang dilaksanakan nantinya. Kreativitas adalah hasil interaksi antara individu dan lingkungannya berdasarkan data atau informasi yang sudah dikenal sebelumnya dari pengalaman yang diperoleh seseorang baik dilingkungan keluarga ataupun lingkungan sekitarnya.( Munandar, 2009: 12)

Metode pelaksanaan kegiatan pengabdian ini dilaksanakan dalam beberapa tahapan sehingga kegiatan ini dapat terlaksana dengan baik. Selanjutnya terkait dengan adanya wabah virus corona ( covid-19) yang sedang melanda berbagai wilayah di Indonesia termasuk wilayah Pesantren Thawalib Gunung, maka segalah hal terkait pelaksanaan kegiatan pelatihan ini nantinya dari awal persiapan hingga pelaksanaan dilapangan wajib mematuhi anjuran protokol kesehatan yang telah ditetapkan oleh Kemendikbud antara lain :

1. Rajin mencucui tangan dengan air mengalir atau menggunakan hand sanitizer untuk mencegah penularan virus antara peserta dan pelaksana kegiatan pengabdian.

2. Seluruh peserta dan pelaksana pengabdian wajib menggunakan masker.

3. Menghindari kontak fisik antara seluruh pelaksana kegiatan.

4. Menggunakan peralatan secara 
sendiri- sendiri dan jika ada peralatan yang digunakan bersama harus memakai sarung tangan.

Ketika pihak sekolah mengetahui bahwa akan dilaksanakannya kegiatan pelatihan lukis kaligrafi di sekolahnya, mereka sangat bersemangat dan antusias sekali. Hal itu dibuktikan dengan kesediaan pihak sekolah menyediakan waktu dan kesempatan kepada siswanya untuk belajar seni kaligrafi tersebut. Untuk menyikapi hal tersebut, maka dirancang suatu proses kegiatan pelatihan yang sistematis dan dapat dipahami oleh siswa. Jika merujuk pada metode pelatihan kaligrafi yang tepat kita bisa berpedoman pada lembaga pelatihan kaligrafi yang ada di Kota Sukabumi yaitu LEMKA (Lembaga Kaligrafi). Menurut LEMKA metode pelatihan kaligrafi yang diterapkan adalah :

1. Metode ceramah, yaitu salah satu metode interaksi belajar mengajar yang dilakukan melalui penjelasan dan penuturan secara lisan oleh guru terhadap sekelompok peserta diklat. Dalam metode ceramah ini juga dilengkapi dengan presentasi dalam bentuk powerpoint untuk memudahkan pemahaman siswa.

2. Metode demonstrasi adalah suatu metode dimana guru menggunakan atau memberikan pertanyaan kepada murid danmurid menjawab, atau sebaliknya.

3. Metode resitasi (pemberian tugas) yaitu suatu bentuk interaksi belajar- mengajar yang ditandai dengan adanya satu atau lebih tugas yang diberikaan oleh guru, dimana penyelesaian tugas tersebut dapat dilakukan secara perorangan ataupun kelompok sesuai perintah guru.

4. Metode latihan/ drill adalah metode dalam pengajaran dengan melatih peserta didik terhadap bahan yang sudah diajarkan/ berikan agar memiliki ketangkasan atau keterampilan dari apa yang dipelajarinya. (Sudjana, 2000:

86).

Dari metode pelatihan tersebut, siswa dan guru nantinya akan dibimbing untuk melalui tahapan kegiatan pelatihan tersebut secara terstruktur. Hal ini merupakan tahapan awal dalam merancang kegiatan pertemuan berikutnya. Dari metode diatas, setiap peserta akan diberikan target untuk mengukur kemampuan sesuai dengan individu masing-masing. Sedangkan guru yang mengikuti kegiatan pelatihan ini, tentunya juga memiliki kemampuan dan pemahaman yang sama tentang metode yang diterapkan. Bagi guru, ilmu yang didapat tentunya bisa 
dibagikan kepada siswa lain ketika siswa yang sekarang ini telah tamat. Kegiatan ini ditargetkan untuk bisa mengembangkan kemampuan yang dimiliki oleh siswa dalam bidang seni luikis kaligrafi. Hal ini bertujuan agar target kegiatan pelatihan ini dapat tercapai. Santri juga diberikan kesempatan untuk mengembangkan desain kaligrafi yang mereka inginkan. Menurut Sachari, desain merupakan inti karya budaya fisik yang lahir dari berbagai pertimbangan fikir, gagas, rasa dan jiwa perancangnya. (Mubarat et al., 2019, p. 103)

Kegiatan ini direncanakan untuk dilaksanakan sebanyak 10 kali pertemuan mulai dari tahapan presentasi sampai akhir kegiatan. Kegiatan presentasi/ ceramah direncanakan selesai dalam 1 kali pertemuan yang dilanjutkan dengan diskusi. Tahap kedua dilanjutkan dengan metode demonstrasi yang ditargetkan selesai dalam satu kali pertemuan. Tahapan ketiga yaitu metode resitasi ditargetkan selesai dalam dua kali pertemuan. Tahapan metode latihan (praktek membuat kaligrafi dari media kertas, triplek hingga kain kanvas dilaksanakan dalam lima kali pertemuan. Dan terakhir adalah tahapan evaluasi kegiatan yang dilanjutkan dengan diskusi tentang kendala yang dihadapi peserta.
Tahapan ini dilanjutkan dengan kegiatan pemajangan /pameran karya yang telah selesai dibuat oleh siswa.. Sedangkan peserta yang akan mengikuti kegiatan ini dipilih sebanyak enam (6) orang putra dan empat (4) orang putri. Pertimbangan dalam pemilihan peserta dilaksanakan berdasarkan minat dan kemampuannya.

Diakhir pelatihan ini nantinya akan dilaksanakan evaluasi kegiatan untuk mengukur dan meninjau sejauhmana keberhasilan dalam pelaksanaan kegiatan pelatihan ini. Evaluasi juga berguna untuk mengetahui sejauhmana efektifitas dari metode pelaksanaan yang dilakukan. Karya yang dihasilkan oleh siswa nantinya akan diapresiasi bersama oleh guru aldan siswa untuk menunjukkan kemajuan yang dialami oleh peserta

\section{B. Pelaksanaan \\ Pelatihan}

kaligrafi

yang dilaksanakan di pesantren Thawalib gunung bertujuan untuk mengembangkan karakter siswa menjadi pribadi yang lebih mandiri dan disiplin. Kegiatan pelatihan ini dirancang dengan sistematik sehingga mudah dipahami oleh siswa. Belajar adalah sebuah proses perubahan dalam kepribadian manusia dan perubahan tersebut ditampakkan dalam peningkatan kualitas tingkah laku dan wawasan yang dimilikinya.(Yulianti \& Marcelina, 2019, p. 81). Sebelum kegiatan ini dimulai, maka tim 
pengabdi mengadakan rapat guna membahas strategi pelaksanaan kegiatan. Dalam rapat ini ditentukan bahwa kegiatan pelatihan ini difokuskan untuk membuat khat tsulus agar lebih cepat dipahami oleh siswa.

Kegiatan pelatihan ini dilaksanakan dalam beberapa kali pertemuan. Pertemuan pertama dilakasanakan untuk memberikan wawasan dan pengetahuan kepada siswa mengenai kaligrafi itu sendiri. Penyampaian materi mengenai kaligrafi itu disertai dengan memberikan modul pelatihan sehingga bisa dibaca oleh siswa. Kegiatan presentasi dengan metode diskusi tersebut bertujuan untuk mengenalkan kaligrafi islam secara khusus ke santri agar mereka bisa memahami jenis khat yang ada di kaligrafi dan bagaimana aturan pembuata khat sesuai ketentuan yang berlaku. Dalam presentasi juga dijelaskan bahwasanya membuat kaligrafi membutuhkan ketenangan fikiran dan kesabaran, karena hal ini berkaitan dengan hasil akhir dari karya yang di buat.

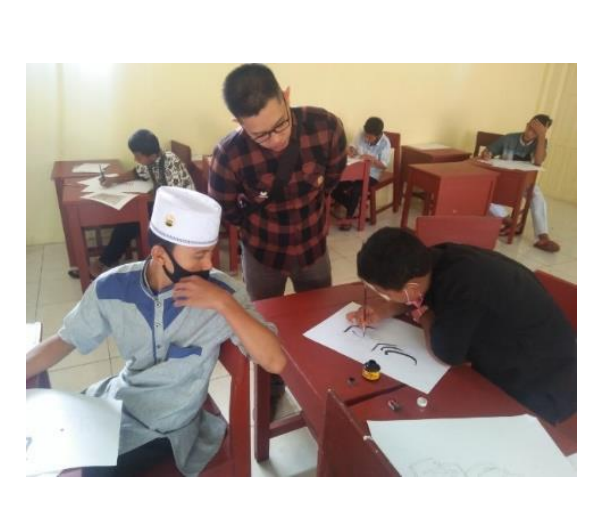

\section{Gambar 2}

Kegiatan presentasi mengenai kaligrafi (Foto Ikhsan, 2020)

Setelah presentasi selesai dilanjutkan dengan diskusi kelas dan tanya jawab mengenai materi yang di sampaikan. Hal ini bertujuan untuk memberikan pemahaman kepada santri mengenai tujuan dari pelatihan kaligrafi islam. Apalagi santri di pesanteran Thawalib Gunung sudah dikenalkan dengan ilmu agama, sehingga dengan mengenal seni kaligrafi akan menambaha kebanggaan mereka terhadap ayat Allah yang ada di kitab suci Alqur'an. Setelah diskusi dilanjutkan dengan latihan pembuatan khat kaligrafi. Karena mereka sudah memiliki dasar tentang membuat khat kaligrafi, maka dalam pelatihan ini, siswa diarahkan untuk belajar khat tsulus, agar lebih mudah dalam penerapannya pada media kertas. 


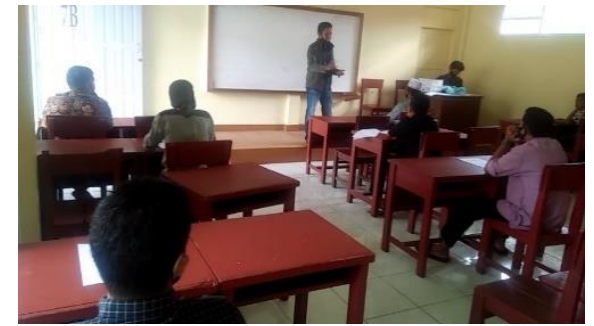

Gambar 3

Kegiatan pelatihan dasar membuat khat (Foto Ikhsan, 2020)

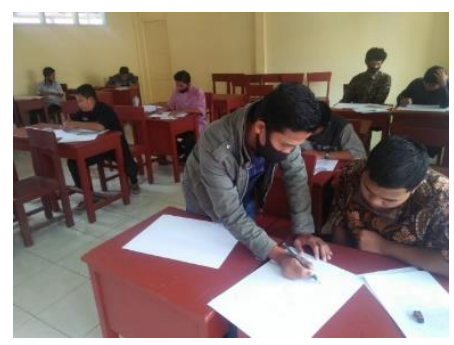

Gambar 4

Membuat khat dengan metode dua pensil (Foto Ikhsan, 2020)

Setelah santri mengenal dasar penulisan kaligrafi di media kertas, maka kegiatan selanjutnya adalah mengenalkan pembuatan kaligrafi di media papan triplek. Pada pembuatan kaligrafi di media triplek ini, pewarnaan menggunakan cat akrilik sehingga bisa menghasilkan warna yang menarik. Selain itu santri juga isa berkreasi dengan membuat ornamen disekeliling kaligrafi yang mereka buat.

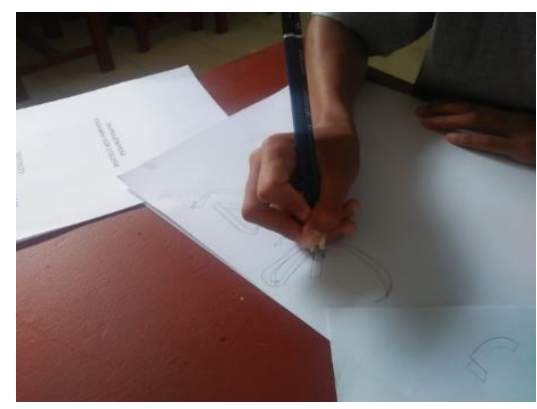

Hal| 121
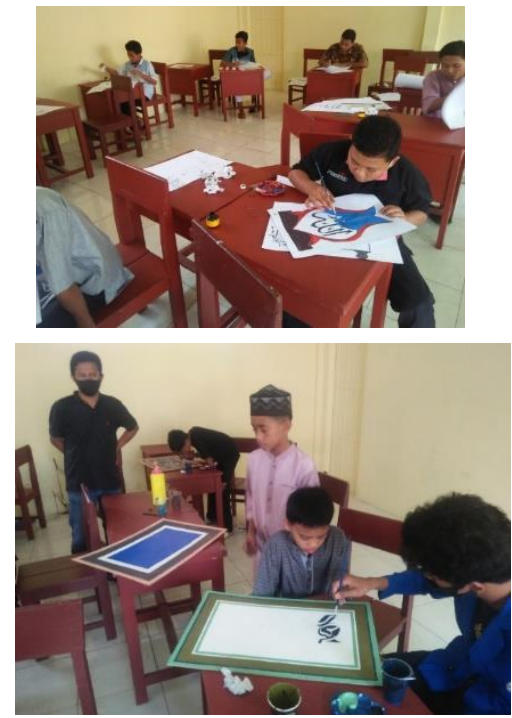

Gambar 5.

Pembuatan kaligrafi pada media triplek (Foto Olvyanda, 2020)

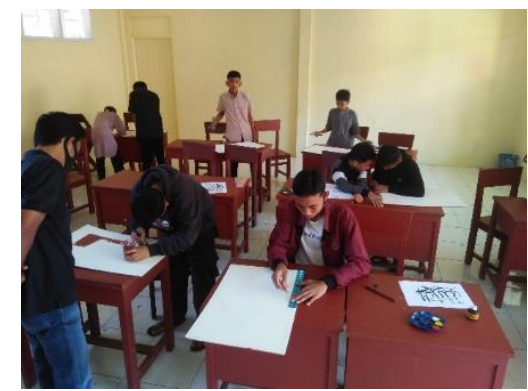




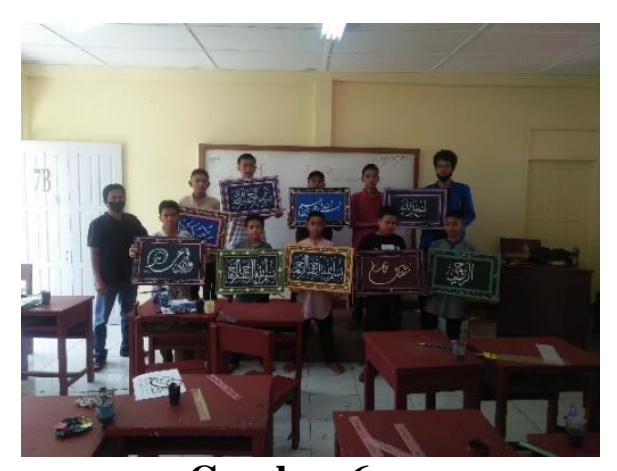

Gambar 6

Hasil karya santri pada media triplek

(Foto Olvyanda, 2020)

\section{SIMPULAN}

Kegiatan pelatihan yang dilaksanakan di Pesantren Thawalib Gunung merupakan suatu upaya untuk mengenalkan seni kaligrafi islam kepada santri. Pesantren modern Thawalib Gunung dengan visi misi untuk mendidik santri yang islami, selalu berupaya untuk meningkatkan kemampuan dan wawasan santri terutama yang berkaitan dengan agama islam. Pelatihan seni kaligrafi islam ini selain bertujuan untuk mengembangkan bakat santri dalam bidang seni rupa, juga bertujuan untuk membentuk karakter santri yang lebih sabar dan teliti. Hal ini dikarenakan dalam pembuatan kaligrafi islam, santri dituntut untuk benar-benar fokus dan sabar dalam membentuk setiap khat sehingga mencapai hasil yang maksimal.

Dalam kegiatan pelatihan ini, santri diperkenalkan untuk membuat khat dengan kalam (sejenis bambu yang diraut). Pembuatan huruf kaligrafi dengan menggunakan kalam tersebut bertujuan untuk mengenalkan kepada santri alat tulis kaligrafi tradisional yang dipakai oleh ulama ulama di zaman dahulu dalam membuat ayat Alquran. Selain itu snatri juga dilatih untuk membuat khat dengan menggunakan kuas dengan media kertas sampai triplek. Hal ini diharapkan dapat mengembangkan bakat santri dalam bidang seni kaligrafi itu sendiri.

Setelah kegiatan pelatihan kaligrafi ini selesai, diharapkan santri dapat mengembangkan kemampuan membuat kaligrafi yang mereka miliki. Hal ini bertujuan untuk semakin meningkatkan kemampuan santri dalam membuat khat. Dengan latihan yang rutin diharapkan bakat bakat yangdimiliki oleh santri bisa semakin dikembangkan.Se lain itu kepada pesantren selaku pembimbing santri, diharapkan juga dapat menambahkan mata pelajaran kaligrafi sebagai bagian dari kurikulum sekolah. hal ini karena kaligrfi sangat dekat dengan islam dan seni kaligrafai tersebut juga bisa menmbentuk karakter siswa menjadi lebih disiplin dan tekun. 


\section{KEPUSTAKAAN}

Ahmadi, Rulam. 2014. Pengantar

Pendidikan. Yogyakarta: AR-RUZZ

MEDIA

Anin Ditto, Yulimarni, S. S. (2020).

Pelatihan Batik Cap dalam Rangka meningkatkan Kreatifitas siswa SLP

YPPLP Kota Padang. Batoboh, 5, 38.

Gunawan, I. (2016). Pelatihan Kaligrafi

Terhadap Tingkat Stress Narapidana.

Psikoislamika : Jurnal Psikologi Dan

Psikologi Islam, 13(1), 39.

https://doi.org/10.18860/psi.v13i1.640

8

Ihsan, muhammad adib. (n.d.).

Pelaksanaan Sistem Pondok dan

Pelatihan Seni Kaligrafi dalam

Meningkatkan Kemampuan. 1-6.

Mubarat, H., Chanaldy, R. S., \& Yanto, D.

(2019). Pengembangan Produk Lukis

Lakuer Menjadi Produk Kerajinan.

Batoboh, 4(2), 96.

https://doi.org/10.26887/bt.v4i2.901

Munandar. 2009. Pengembangan

Kreativitas Anak Berbakat 1. Jakarta.

Rieneka

$$
\text { Cipta }
$$

Sirajuddin AR D. 1988. Seni kaligrafi

Islam. Jakarta: Pustaka Panjimas.

Sundari, S., Widdiyanti, W., Yanuarmi, D., \& Ditto, A. (2018). Ekstrakurikuler Batik Di Man 2 Kota Bukittinggi. Batoboh, 3(2), 92.

https://doi.org/10.26887/bt.v3i2.522

Yanuarmi, D., Widdiyanti, W., \& Sundari,

S. (2019). Kreatifitas Melalui Batik

Cap Dari Karton Bekas Pada Siswa

Disabilitas. Batoboh, 4(2), 69.

https://doi.org/10.26887/bt.v4i2.899

Yulianti, E., \& Marcelina, D. (2019).

PELATIHAN PEMBUATAN BAHAN

AJAR UNTUK SISWA SEKOLAH

DASAR. 3(2), 79-85 